\title{
日本近海に発生する有機眵濁物に関する研究 (予報)*
}

\author{
辻田時 美 \\ (西海区水産研究所)
}

\section{A Preliminary Study on Naturally Occurring Suspended Organic Matter in Waters Adjacent to Japan}

\author{
By
}

\author{
Tomiki Tsujita \\ (Seikai Regional Fisheries Research Laboratory)
}

\begin{abstract}
In waters adjacent to the south-western coasts of Japan, especially on the coast banks off Kyushu, it has long been recognized that the dark green or gray, large, formless suspended organic matter appears from late autumn to early summer in every year. According to reports from pelagic fishing boats of the Japanese bonito and tuna fishery, we can know on naturally occurring of the larger suspended organic matter in oceanic water of the Warm Current of Kuroshio.

Although the people of the Japanese bonito fishery and tuna fishery had for a long time known about occurring seasons and areas of the matter, and any investigation on the mechanism and place of generation of such suspended organic matter has never been researched scientifically. In offshore waters of the Goto Islands of the western Kyushu and in almost every year, the larger organic matter can be seen intermittently in the surface-layer or at the surface of the waters near by the Goto Islands. The people in this district call the appearance of the larger organic matter "Shiogusare has come" when this appears.

Fishermen of the Pelagic fishery of bonito and tuna find often this kind of suspended organic matters much in offshore waters of the western part of the North Pacific Ocean, several hundreds miles far off the coast and in the Eastern Sea. It is called "Yogore" as its another name, and the people of the sett net fishery of the coastal regions and sailors of the coastal lines call it "Nuta". It is popularly known that there is some relationship between the appearance of "Nuta i.e. Shiogusare" and the fishing conditions, while not only as the nature or constituent of itself but also about the mechanism of appearance is not known clearly.

Some people say the appearance of the matter is bad for the fishery, but others say it is good. The author can consider that the suspended organic matter has at least some relations to fishing conditions, for instance, it seems that the season of its appearance relates closely to oceanographic conditions and meteorological conditions.
\end{abstract}

On the other hand, when the matter appears the anchor rope of vessels

* 農林省 西海区水産研究所業績 第 4 号 
and fishing nets are stickled with them and are hastened to decay. In this point of view, fishermen and sailors think them unprofittable. The author had the wish to make a through investigation of nature of the matter and mechanism of the appearance, and then got a chance when he could find a generating state of the matter during the oceanographic research on the Goto Nada area held in April 1948.

Since that time, he has biologically studied about the naturally suspended organic matter, and as he got some of knowledge, he will report on the matter. Owing to some conclusions drawn by him, it became clear that they belong to a kind of materials of plankton origin, as some results of microscopic examination on the structure of the materials collected. And at first he tried to research the biological construction and the origin of the matter. The larger suspended organic matter found in waters adjacent to Kyushu is formed after explosive multiplication of plankton, and then in the view of the biotic structure the matter consists of two constituents, the one is matrix, the other plankton community. These constituents are represented in Figures and Plate 1. As mentioned above, it follows that the larger suspended organic matter is formed out of plankton in the water mass in which plankton population grows explosively.

\section{は しが}

九州西南海域には例年晚冬から初夏にかけて，扊緑色竽は死色の大形無定形の有機

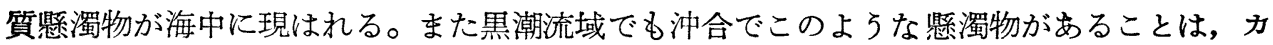
ツオ，マグロ漁船などの報告に散見される。

このような物質の浮游時期と出現海域は古くから漁師や航海者などが知つていたので あるが，その発生機構と発生場所については従来から科学的に調べられていない。

九州西海域の五島列島近海では殆んど毎年 2 月から 4 月纴 6 月までの間に，大形の 有機懸濁物が断続してあちこちの海中に見られ，この地方ではこれが現はれると“潮腐れ” がきたと称している。カツオ，マグロなどの遠洋漁業者は太平洋の数百浬沖合や支那東海 でも屢々この種の䯚濁物が多量浮流するのを認めるのであつて, 別名“ョゴレ”と呼んで いるが，沿岸の定置網漁師達や近海航路の船乗り達は“ヌタ”とも言う。このヌタの出現 即ち “潮腐れ”と漁況との関係については各地で色々と港間の憶説もあるが，その発現の 機構は勿論のこと，そのもの自体の性質とか構造ははつきり判つていないのであつて，あ る者はこれが現はれると漁に悪いと言ひ，ある者は漁が良くなるとも言う。

しかしこの有機質の䀣濁物は出現の時期が海象気象と密接な関係にあるらしい点から 考へれば，少くとも漁況と関係があることは察せられる。他面これが現はれると，船舶の 錯綱や漁業では網や綱に附着してそれらの腐敗を早めるので，この点からは漁師や航海者 にとつては有害なるものとなつている。

著者はこのような懸濁物がどんな性質のものであつて如何なる発生の機構を有する のか，また海洋の生産過程とか物質循還に関してはどういう意義があるのかなどのことを 究めよ5と思つていたところ，機会を得て 1948 年の春に行つた海洋調查の時にその一端 
を知ることができた。その後海洋調查を実施する度に有機懸濁物の調査をる併せ行ひ, 若 干の知見を得るに至つたので報告する。

即ち試料を採集して顕微鏡によつてその構造を調べてそれが Plankton origin のも のであることが判つたので, 最初にその生物学的構造とその成因を追求することにした。

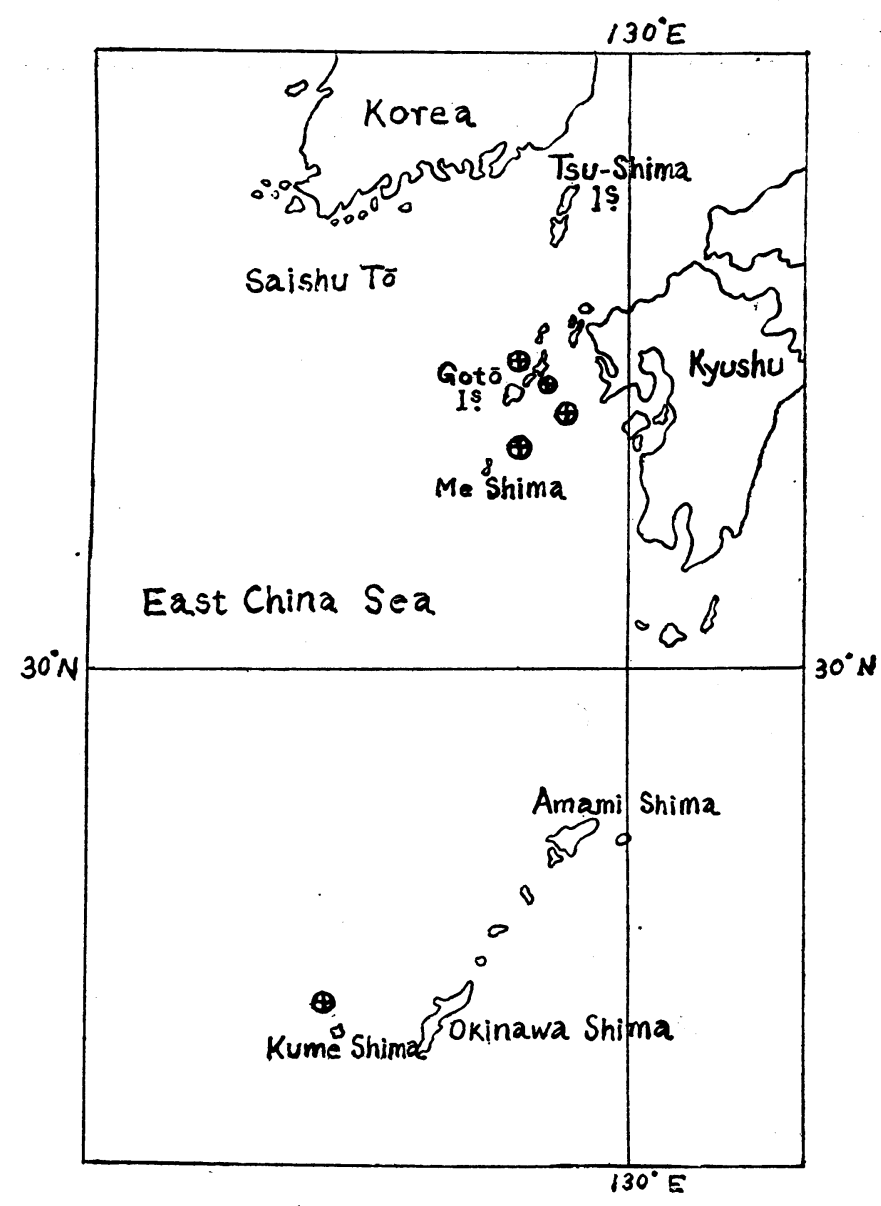

Chart showing the localities where naturally suspended organic matters $\oplus$ have been taken.

\section{二, 三の有檴惩濁物の構造と分布}

試料は Plankton 採集の場合と同様に, 海水中に懸濁したま〉のものを船上から Plankton ネットやバケツで汲取つて，ホルマリンで腐敗を防止しておいたるのを持帰つ て顕微鏡によつて観察した。 


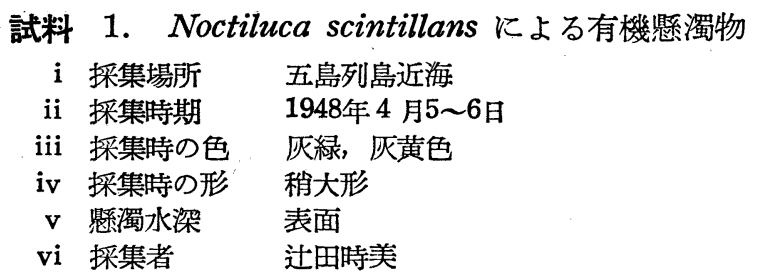

この試料には 2 種類あり, 五島列島西側海面で採集したもの（A）は新鮮で形成直後 の状態を示し，Planktonの Chromatophore がまだそのま〉の色を呈して残つていた。

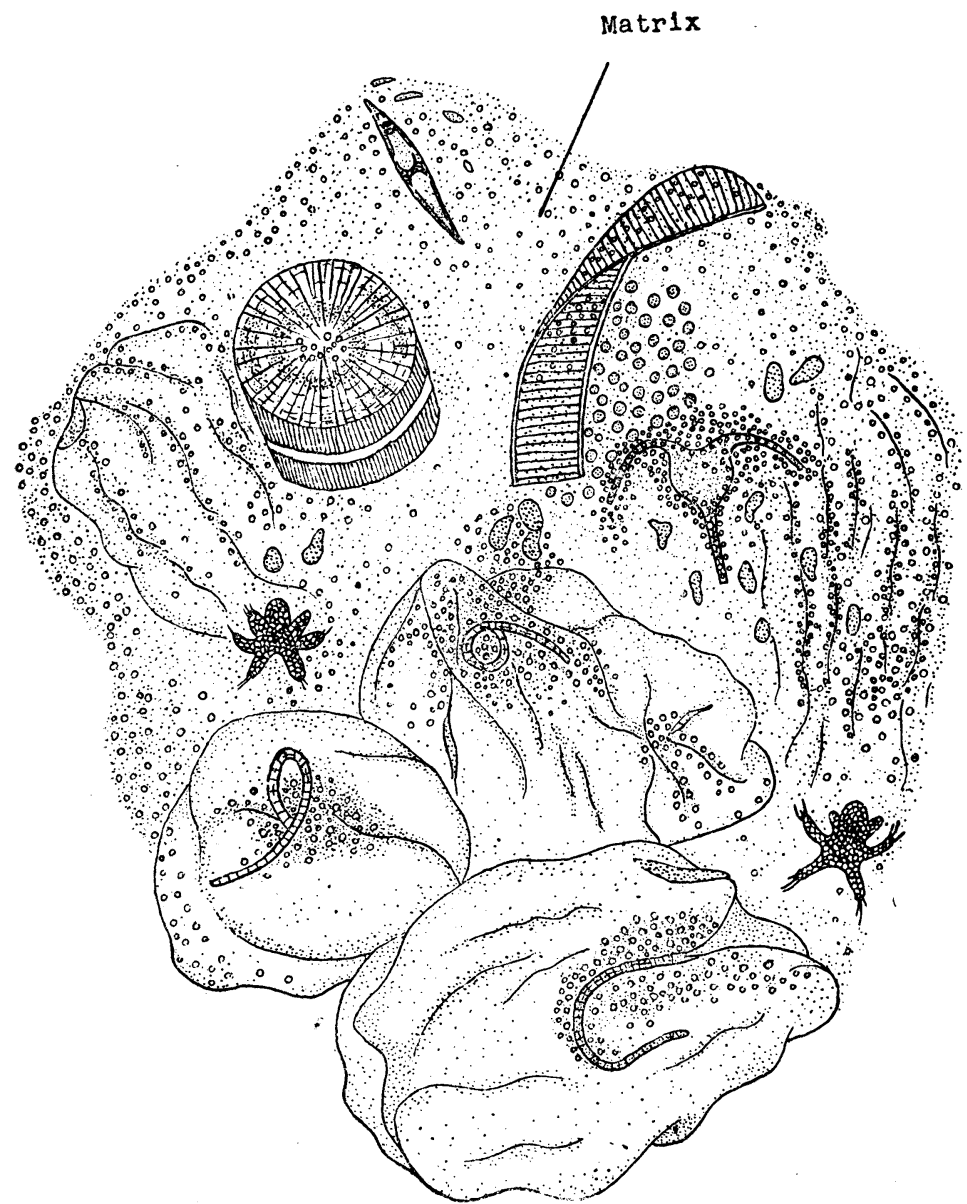

Fig. 1. A. Microscopic drawing of a fragment showing biotic construction of the suspended organic matter of the matrix consisting of Noctiluca scintillans; hauled at the surface 5 miles west of the Goto Islands on the 5th April, 1948. 


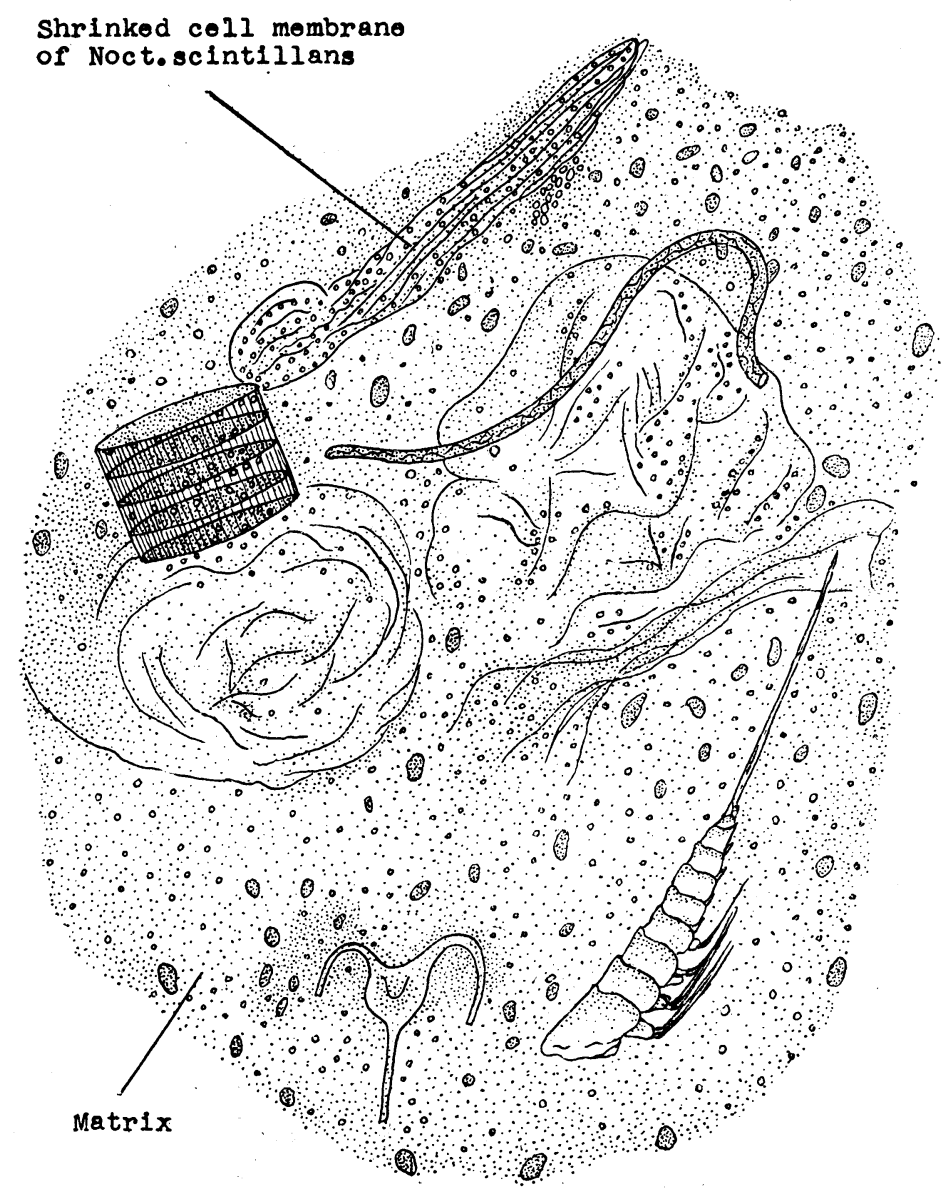

Fig. 1. B. Microscopic drawing of a fragment showing biotic construction of the suspended organic matter of the matrix consisting of Noctiluca scintillans; hauled at the surface 10 miles east of the Goto Islands on the 4th April, 1948.

その生物的構造は Fig. 1. A, B 及び Plate 1, Fig. 1 に示すように, 崩壊した細胞の Cytoplasm や Chromatophore, Cell-organ（夜光虫など原生動物の場合）々か Valve (Diatom などの場合) などから成る Gel 状の母体1)があつて, これに多数の Plankton が混入したり附着したりした状態が見られる。顕微鏡によつて見た構造は，この Matrix は Noctiluca scintillans の細胞が死後 Cytolysis によつて Protoplasm が海中に露出し て無定形の小塊片となつたもので, この Gel 状の Matrix が形成される時には, 夜光虫 の若干個体の Cytolysis と同時に海水中に露出した Protoplasm が Coagulate する時に

1）これは基質 Matrix と呼んだらよかろう。 
夜光虫の細胞膜も同時に混在し，この時に僅少ではあるが周辺海水中の微細な Plankton も混入する。そこに含まれている Plankton の種組成をこの䀣濁物の生物的第 1 次組成と すれば, Matrix と生物的第 1 次組成から成る有機䯚濁物は最も新しい形成直後の状態, 即ちこれは有機懸濁物の構造及び性質の転化からみた場合には形成初期のものである。 (Fig. 1 及び Tab. 1. A 参照)。この䀣濁物の Matrix の一部を成す Coscinodiscus gigas の Chromatophore はこの Stage にはまだ明瞭に認められる2)。

このようにして出来た有機懸濁物が浮游中に, その過程において海中の Plankton が 吸着されたり Matrix に寄生したり.して, ある期間に亘つてそれら Plankton の数が増 加していつて, 生物的第 2 次構造を生ずるに至る。この䯚濁物が附着 Plankton に基く生 物的第 2 次構造を示す段階に到達した時は, その䯚濁物の組成 Plankton は最も多種多 様で，その状態は Tab. 1. B に示すょうに，採集した場所の海中懸濁物周辺海水中の Plankton community よりも種組成は複雑となつている。しかしこの懸濁物の眯濁漂流 期間が或程度経過すると Gel 状の Matrix に変質が起つてきて Plankton の附着は行 はれなくなりまた寄生も行はれなくなつて，更に時間が経過するにつれてむしろ反対に Plankton が脱落するようになり, 組成 Plankton は種数も数量もともに減少する。従つ て有機懸濁物の組成 Plankton の最大量が現はれるのは時間的に限界がある。

また夜光虫が Matrix を作つているこの試料についてみると, Matrix 中に應敗栄養 を営む Dinoflagellata の類が多く, Silicoflagellata の如きは Tab. 1によつても知らる ১よ5に, 生物的第 2 次構造において周辺海水中の Plankton community と比較して相 当に優占的な順位を示している。このことは Cytoplasm に富んだ Planktonより成る有 機懸濁物例へば夜光虫の場合のような懸濁物の Matrix は, 新しい程 Plankton の繁殖 に適した培養基の働をしたり，原生動物類の寄生に適するのではないかということを暗示 する。次に懸濁物の生物的構造に関して, その組成 Plankton と, 同時に採集した海水中 の Plankton の種組成との Community の関係を 1948 年 4 月 4 - 6 日に採集した試料 についてみると次のようである。(Tab. 1 参照)

海水中の Plankton の Dominant species は五島列島の東側海面に打ける場合も, 西側海面における場合も同様に Noctiluca scintillans で，第2 位を占める種はCoscinodiscus gigas が举げられる。しかして五島列島西方海面においては, Noctiluca scintillans による赤潮の大規模のものが出現中であつたが，東側海面では赤潮は見られ なかつたけれども Noctiluca scintillans による赤潮が終息した後であつたことは, 懸濁 物の Matrix が Noctiluca scintillans で, 現場海水中の Plankton community の Dominant species が Noctiluca scintillans であり，また有機懸濁物の生物的構造及び その外囲海水中の Plankton の種組成において, 種数の順位として第2 位を占めるのは Coscinodiscus gigas が挙げられる (Tab. 1, B 参照)。

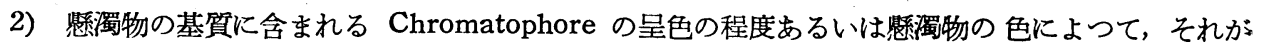
発生後新しいか古いか凡そ判定される。 
Table 1. Comparison of plankton communities between suspended organic matters and sea waters in situ

A. Western area of the Goto Islands (Hauled on the 5th April, 1948)

\begin{tabular}{|l|c||r|r|}
\hline Suspended organic matter & & Sea water & \\
\hline Noctiluca scintillans & $\mathrm{C}$ & Noctiluca scintillans & $\mathrm{CC}$ \\
Coscinodiscus gigas & + & Coscinodiscus gigas & $\mathrm{C}$ \\
Pleurosigma affini & + & Paracalanus parvus & $\mathrm{R}$ \\
Dictyocha fibula & $\mathrm{R}$ & Coscinodiscus sp. & $\mathrm{R}$ \\
Paracalanus parvus & $\mathrm{R}$ & Ceratium sp. & $\mathrm{RR}$ \\
Laudelia borealis & $\mathrm{RR}$ & Parafavella denticulata & $\mathrm{RR}$ \\
Nitzschia longissima & $\mathrm{RR}$ & Brachyura zoea & $\mathrm{RR}$ \\
\hline
\end{tabular}

B. Eastern area of the Goto Islands (Hauled on the 4th April, 1948)

\begin{tabular}{|l|r||l|r|}
\hline Suspended organic matter & & Sea water & \\
\hline Noctiluca scintillans & $\mathrm{C}$ & Noctiluca scintillans & $\mathrm{CC}$ \\
Coscinodiscus gigas & + & Coscinodiscus gigas & $\mathrm{C}$ \\
Nauplius of Copepoda & + & Nauplius of Copepoda & $\mathrm{RR}$ \\
Pleurosigma affini & + & Chaetoceros didymum & $\mathrm{RR}$ \\
Nitzschia longissima & + & Ceratium symmetricum & \\
Nitzschia seriata & + & & \\
Chaetoceros Eibenii & $\mathrm{R}$ & & \\
Rhizosolenia setigera & $\mathrm{R}$ & & \\
Distephanus speculum & $\mathrm{RR}$ & & \\
Distephanus sp. & $\mathrm{RR}$ & & \\
Gazelletta hexanema & $\mathrm{RR}$ & & \\
Ceratium tripos & $\mathrm{RR}$ & & \\
Microsetella rosea & $\mathrm{RR}$ & & \\
Oikopleura sp. & $\mathrm{RR}$ & & \\
\hline
\end{tabular}

Tab. 1 において, A !五島列島西側のもの)，とB（同東側海域のもの）を比較対照し てみると, 五島列島西側海域に打ける場合は眯濁物の生物的構造中の Plankton と現場海 水中の Plankton の種組成には大差なきかむしろ眯濁物中の Plankton が貧相な状態にあ るが; 五島列島東側海域（五島灘）の場合には可なり顕著な相違が見られ, 懸濁物の生物 的構造は遥かに複雑で海水中の Plankton community の種組成は単調である。

即ち Tab. 1, A (五島列島西側) の場合には㲘濁物の生成初期の状態が見られ，その Plankton はFig. 1, A に示すように生物的第 1 次構造の状態と見られ, 且これが新鮮な ものであることは Coscinodiscus gigas その他の色素粒が带色の状態で多数認められたこ とでも明らかである。 B. (五島列島東側海面のもの) を見ると, 賏濁物の生物的構造は稍 
複雑なるに反して海水中の Plankton community は種組成の点では単調で, また海水中 の Plankton 々酥濁物中の Plankton の質的相違も可なり大きく, しかも後者には色素 粒が認められない。このような理由によつて，4 月 4 日に五島灘で採集した有機䯚濁物は 生成後既にある程度時間を経過して生物的第 2 次構造の段階に移りつむるるものと推定さ れる。乙かしその生成に関する生物学的機序は 4 月 4 日採集の五島列島東側海域のものと 4 月 5, 6 日に採集した五島列島西側海域のものとは同じく Noctiluca scintillans の異 常繁殖（俗には夜光虫の赤潮）によることは, 晒濁物の Matrix が両者ともにNctiluca scintillans であると同時に, 海水中の Plankton community が単調であることでも知ら れるのであつて, 特に五島列島西側海面に执いては Plankton の異常繁殖 (赤潮) の主成 Plankton (優占種) たる Noctiluca scintillans から出来つつある䯚濁物が観察され且採 集された。

また海中の Plankton community が単調であることは, 有機懸濁物が発生する以前 に Planktonの繁殖に排除作用が起つたことを示し, 特定の Plankton の 1 万至数種が懪 発的に繁殖し, それまでに存在した多くの他の種が 捕食されたりして Plankton community の種組成は単調となる反面, Population density が大きくなる所謂異状繁殖が起 つたことを示すもので, この場合 Noctiluca scintillans を優占種として Coscinodiscus gigas がそれに随伴した種となつていることは Tab. 1 の示す通りである。しかしその原 因については今後の研究に俟たねばならない。

\begin{tabular}{rll} 
試料 2. & \multicolumn{2}{c}{ Trichodesmium erythraeum による有 } \\
i & 採集場所 & 久米島 (琉球列島) 北西 20 浬 \\
ii & 採集時期 & 1948年 6 月 1 日 \\
iii & 採集時の色 & 灰黄色 \\
iv & 採集時の形 & 中形 \\
v & 懸濁水深 & 表面 \\
vi & 採集者 & 西崎重信 (第 8 新洋丸船長)
\end{tabular}

この懸濁物は Matrix が Trichodesmium erythraeum より成り，その生物的構造は Fig. 2 と Plate 1, Fig. 2 並びに Tab. 2 に示した通りで, Trichodesmium erythraeum の Colony と個々に分離した細胞の集合を Matrix としてこれに Tintinnus, Rhabdonella など暖海性の有鐘繊毛虫類 Tintinnoinea が多種類含まれ, これにCoscinodiscus など Diatom の若干種が 加はつてこの懸濁物の生物的構造の主成分をなし, 明らかに Trichodesmium erythraeum の大量繁殖 (Biological colouration) の結果, これを Dominant species とする単純ではあるが Population density の大きい Plankton community が形成されて, これが Matrix となつて出来たことを示している。この Biotic community に括いて一考すべき点は Tintinnoinea の出現は一般的には Diatom 類の 量的変化と平行関係にあるとされているが，この䯚濁物の生物的構造についてみると Diatom の類が殆んど見られない。

このことは綮濁物の Matrix が形成される時の周辺海水中において Diatom の 


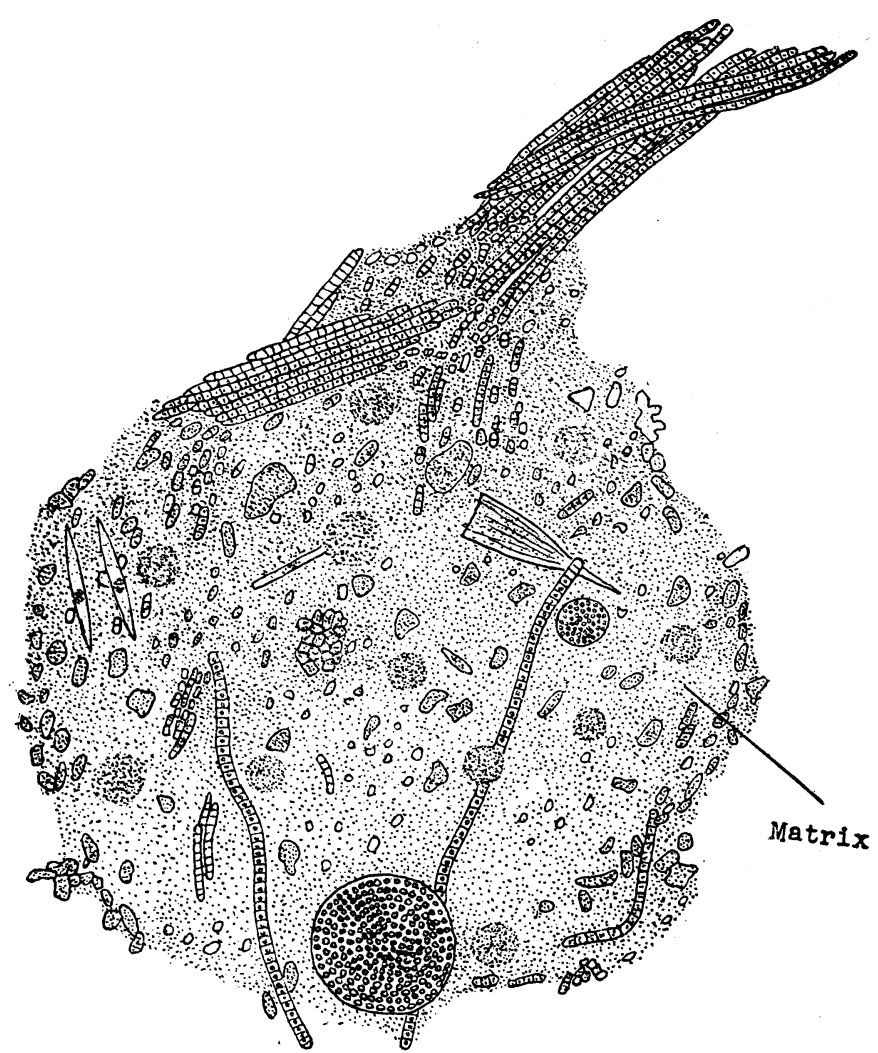

Fig. 2. Microscopic drawing of a fragment showing biotic construction of the suspended organic matter of the matrix consisting of Trichodesmium erythraeum; hauled at the surface 20 miles north west of Kume Shima of the Ryukyu Islands on the 1st June, 1948.

Table 2. A plankton community of the suspended organic matter originated from Trichodesmium erythraeum.

Sample No. 2; hauled at the surface on the 1st June, 1948; location, 20 miles NW off Kume Shima of the Ryukyu Islands.

Trichodesmium erythraeum

Rhabdonella striata

Rhabdonella sp.

Epiplocylis undella

Tintinnus frankoi

Prorocentrum $s p$.

Bacillaria sp.

Grammatophora marina

Coscinodiscus oculus-iridis

\begin{tabular}{|l|}
\hline $\mathrm{CC}$ \\
$\mathrm{R}$ \\
$\mathrm{R}$ \\
$\mathrm{R}$ \\
$\mathrm{R}$ \\
$\mathrm{R}$ \\
$\mathrm{R}$ \\
$\mathrm{R}$ \\
$\mathrm{R}$
\end{tabular}


Population density が小さかつたためであるか，あるいはこの懸濁物が生成後可なりの時 間を経過して，その間に脱落したかいづれかの場合であることを示している。しかしてこ の懸濁物は Tab. 2 によつて知る通り, 生物的構造の特徴としては Ciliataが多いので, Matrix の生成後既に可なり時間を経過して生物的第 2 次の構造段階に移りつつある状態 と思はれる。

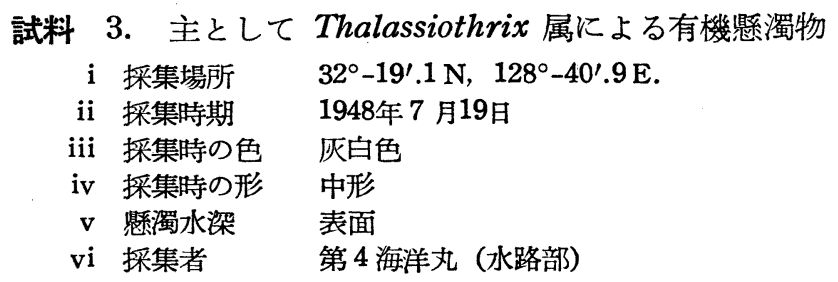

この有機懸濁物の Matrix は Thalassiothrix の類で, これに Chaetoceros decipiens, Ceratium macroceros が生物的構造の 主成分をなしており, その他若干の原生動物が含 まれている (Plate 1, Fig. 3 参照)。この㲘濁物が上の 2 の試料と異るのは Diatom が Matrix を成して拈り，乙かも組成 Plankton に Chaetoceros の類が見られることであ る。そして Species の数が比較的少いのは前の試料と同じく Thalassiothrix の Explosive multiplication 即ちそれらの Quantum adaptation3) の結果として Thalassiothrix 属の若干種が優占し，それによつて Matrix が形成されたものであろう。

この懸濁物は以上の生物的構造と微細な Plankton が少い点から, 第 1 次構造の段階 にある懸濁物と推定される。

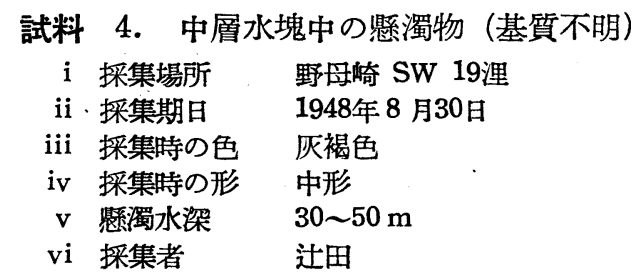

この懸濁物の生物的構造は Fig. 3 及 Plate 1, Fig. 4 並びに Tab. 3 に示す通り, 組成 Plankton の殆んど大部分の Species が Diatom に属する懸濁物で, Thalassiothrix 属中の 3 種即ち Thalassiothrix nitzschoides, Thal. Frauenfeldii, Thal. longissima が 最多となつて明らかに Dominant group となつているが, 特に何種が Dominat species でいづれが随伴種であるかという識別は困難である。そしてこの懸濁物の Matrix を見る と, 試料 3 の Thalassiothrix 属を Matrix とする懸濁物と全く異つて Gel 状のるので ある点から，この懸濁物は Thalassiothrix 属を Matrix として出来たものではないこと が言へるのであつて, Matrix の性状から判断して恐らく Trichodesmium 属を Matrix

3) Genetics, Paleontology, and Evolution. 1949. NY., USA. 
とする䀣濁物であろうと推定する。

この眯濁物の生物的構造を見ると (Fig. 3), 組成 Plankton の Species が多いこと 〉量的にも多いことが特徵で, 従つてこのような生物的構造の複雑性よりみると, 生物的 第2 次構造の過程にあるものと思はれる。しかして九州西方近海の Plankton community の季節的変化からみると, 7〜8 月には Thalassiothrix 属, Asterionella 属などが優占す る時期であるから，この䀣濁物の Matrix は時間的に可なり以前に形成されて，その懸濁 する水塊も可なりの距離を輸送されて, 五島灘の野母埼沖合に入つたものであることが考

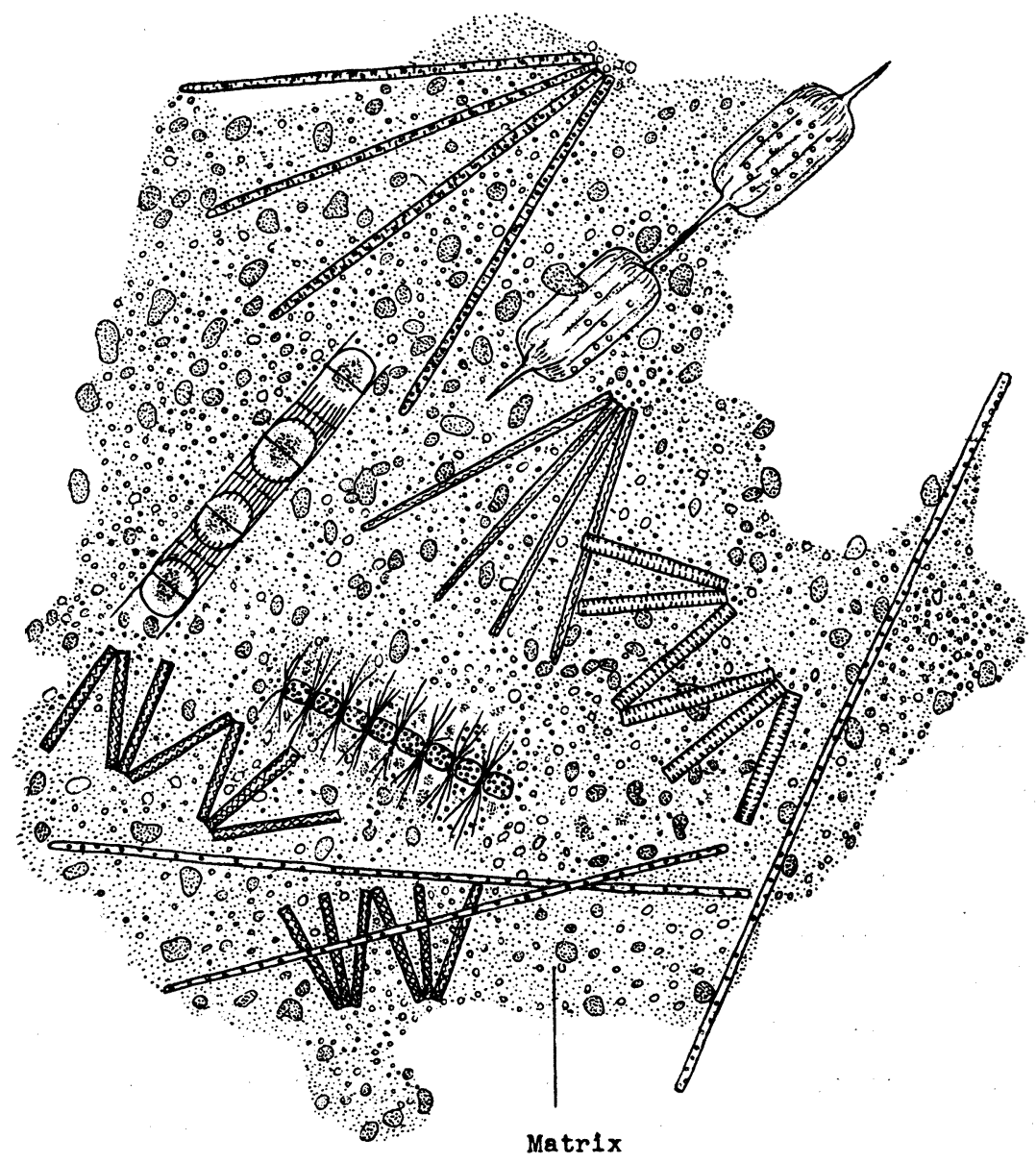

Fig. 3. Microscopic drawing of a fragment showing biotic construction of the suspended organic matter of the matrix consisting of Trichodesmium (?) found in the water mass of the bottom layers on sardine fishing ground off Nagasaki; hauled on the 31st August, 1948. 
へられるので, この Matrix の生物的構造は第 2 次的にこの近海に達してからその水塊中 で形成されたように観察される4)。

Table 3. A plankton community of the suspended organic matter originated from diatom in the water mass of the middle layer.

Sample No. 3; hauled at a depth of 50 30 meters in the sardine fishing ground 19 miles W off Nomo Zaki on the 30th August, 1948.

\begin{tabular}{|l|r|}
\hline Thalassiothrix nitzschioides & $\mathrm{CC}$ \\
Thalassiothrix Frauenfeldii & $\mathrm{CC}$ \\
Thalassiothrix longissima & $\mathrm{CC}$ \\
Ditylum Brightwelli & $\mathrm{C}$ \\
Stephanopyxis turgida & $\mathrm{C}$ \\
Rhizosolenia setigera & + \\
Rhizosolenia sp. & + \\
Chaetoceros decipiens & + \\
Leptocylindrus danicus & $\mathrm{R}$ \\
Bacteriastrum varians & $\mathrm{R}$ \\
Eucampia zoodiacus & $\mathrm{R}$ \\
Rhabdonella conica & $\mathrm{RR}$ \\
Rhabdonella sp. & $\mathrm{RR}$ \\
Ceratium candelabrum & $\mathrm{RR}$ \\
Nauplius of Copepoda & $\mathrm{RR}$ \\
Microsetella norvegica & + \\
\hline
\end{tabular}

考

察

1948年 4 月 4 日以降, 九州近海の海洋調查, 漁船便乗調査その他の機会を得て採集し た大形の有機質䊬濁物は, その生物的構造を顕微鏡によつて調べると, それは Plankton から出来るもので, しかもある種の Plankton の異常繁殖の場合に形成されること即ち Population density がか〉る大形有機懸濁物の発生を支配する一つの生態的条件のよ5 である。このことは1948年 4 月上旬の五島列島近海の海洋観測の際に, 夜光虫の赤潮が発 生している海水の観測を行うことが出来て, 有機懸濁物が形成されつ〉ある現場を観察し 且試料の採集を行つて, その蔝濁物の生物的構造を研究することによつて一つの事実を明 らかにすることが出来た。そしてこの後, 黒潮域及九州近海で採集されたものはいづれる Plankton のある特定の種か丈は属の大量繁殖の結果出来ることを示す生物的構造である ことを知つた。

更にこれら色々の試料の構造をみると, 異常繁殖をした Plankton が死んで疑塊とな つた基質 Matrix とも言うべき部分を有機質の母体として，これに附着したり寄生したり する Plankton community の部分が考へられる。しかしこれが時間を経て古くなると

4）辻田：1949. 長崎近海の二重潮の研究（予報） 
Plankton community は見られなくなることは, 沿岸では時化などの際に浮上つてくる 懸濁物“ヌタ”であつたり，また Detritus として海底に沈澱して Benthos の栄養源に なつたりする有機物で

海中で自然に発生する有機晒濁物には Particulate organic matter, dissolved organic matter などが知られているが，著者がこつに報告しまた今後続いて研究される 大形の有機瀋濁物は, 上の 2 種類の Organic matter とともに海洋に打ける物質循還の一 過程にあるものであるが，ぞちらかと言うと大形の有機懸濁物は Particulate organic matter の一つの特例と考へられる巨視的な過程を示するのであろう。

海洋生態学的には, 著者が示している有機䀣濁物の発生には, 時間的にも空間的にも また Planktonの Population dynamics の観点からも特定の条件が必要である。 